https://doi.org/10.52240/1857-2367.2020.2(21).41

\title{
INIŢIEREA FONDĂRII COLECT,IEI DE PLANTE MELIFERE ÎN CADRUL GRĂDINII BOTANICE NAȚIONALE (INSTITUT) „ALEXANDRU CIUBOTARU”
}

\author{
Natalia CÎRLIG, Aurelia LUPAN, Victor ȚITȚEI, Ana GUȚU, \\ Elena IURCU-STRĂISTARU \\ Grădina Botanică Națională (Institut) „Al. Ciubotaru”, \\ Chișinău, Republica Moldova
}

\begin{abstract}
At the "Al. Ciubotaru" National Botanical Garden, a collection of honey plants has been founded. It includes annual and biennial plants with different growing seasons and flowering stages, starting in May and ending in October, so that there is a staggered blooming of honey plants throughout the growing season and a source of nectar and pollen for pollinating insects of different taxonomic families, particularly honeybees.
\end{abstract}

Key words: honey plants, collection, flowering stage.

Pentru organizarea unei baze furajero-melifere eficiente este necesar de a valorifica pe deplin potențialul plantelor, iar valoarea meliferă a florei naturale reprezintă un criteriu important. Este necesar de a identifica plante anuale, bienale și perene cu perioade diferite de înflorire, care să asigure din aprilie până în noiembrie o sursă nutritivă atât de nectar cât și hrană pentru albini, fluturi și alte insecte benefice (dușmani naturali ai insectelor dăunătoare) [2]. În literatura de specialitate se cunosc peste 1.000 de specii de plante melifere, din care circa 200 sunt importante pentru apicultură. Plantele sunt clasificate în dependență de perioada înfloririi - primăvara timpurie, primăvara, vara şi toamna. Altă clasificare cu caracter practic împarte plantele melifere în: plante agricole cultivate, pomi şi arbuşti fructiferi, plante de pădure, plante melifere din fânețe şi păşuni, plante special cultivate pentru albine [3]. Plantele melifere sunt speciile care asigură materia primă necesară supraviețuirii şi dezvoltării albinelor. În funcţie de potenţialul economico-productiv (kg/miere/ha), sunt plante cu potenţial mare $(150-200 \mathrm{~kg} / \mathrm{ha})$, mediu (20-45 kg/ha) şi mic (10 kg/ha) [1].

În cadrul Grădinii Botanice Naționale (Institut) „Alexandru Ciubotaru”, pe sectorul experimental al laboratorului Resurse vegetale în anul 2020 a fost inițiată colecția de plante melifere cu scopul identificării și mobilizării genofondului de plante valoroase, de perspectivă pentru Republica Moldova, cu îmbogățirea ulterioară a sortimentului de specii și soiuri, efectuarea cercetărilor referitoare la particularitățile biologice de creștere și dezvoltare a plantelor melifere în condițiile climatice ale țării. Cele mai valoroase plante melifere din colecție sunt: facelia (Phacelia tanacetifolia Benth., familia Hydrophyllaceae R. Br.); lucerna, trifoiul (Medicago sativa L., Trifolium sp., familia Fabaceae Lindl.); silfia, floarea-soarelui și topinamburul (Silphium perfoliatum L., Helianthus annuus L., H. tuberosus L., familia Asteraceae Bercht. \& J. Presl) ș.a. Studiul de față se referă la unele specii de plante din colecție cu importanță sporită pentru sectorul apicol.

Fagopirum esculentum Moench - hrișca comestibilă (familia Polygonaceae Juss.). Plantă anuală cu semințe comestibile, cultivată și ca plantă meliferă. Oferă albinelor 
hrană pe parcursul unei luni (a doua decadă a lunii mai-iunie) cât durează perioada de înflorire.

Onobrychis arenaria (Kit.) DC. - sparceta de nisip (familia Fabaceae Lindl.). Plantă perenă, caracterizată ca plantă meliferă valoroasă. Perioada de înflorire durează circa 30 de zile (lunile iunie-iulie). Florile de sparcetă sunt intens cercetate de insectele polenizatoare, îndeosebi albinele melifere și bondari.

Cynara cardunculus L. - anghinare (familia Asteraceae Bercht. \& J. Presl). Plantă perenă erbacee, ce se cultivă pentru consumarea solzilor cărnoși ai înflorescenței și receptaculii florali. În colecția Grădinii Botanice perioada de înflorire coincide calendaristic cu luna iulie.

Inula helenium L. - iarba mare, lacrimile Elenei (familia Asteraceae Bercht. \& J. Presl). Plantă perenă, erbacee, robustă. Perioada de înflorire se înregistrează în prima decadă a lunii iulie și ultima decadă a lunii august, uneori și prima decadă a lunii septembrie în dependență de condițiile climatice înregistrate. Trec în perioada generativă începând cu anul doi de vegetație. Florile galbene sunt grupate în capitule mari, înflorirea este eșalonată, ceea ce face plantele atractive pentru insecte o perioadă mai îndelungată de timp.

Isatis tinctoria L. - drobușor (familia Brassicaceae Burnett.). Plantă erbacee, bienală sau perenă. În ultimii ani se cultivă ca plantă meliferă cu potențial înalt. Florire galbene, mici sunt adunate în raceme. Înflorește abundent începând cu jumătatea lunii mai până la mijlocul lunii iunie şi durează 25-30 de zile.

Lotus corniculatus L. - ghizdei (familia Fabaceae Lindl.). Este o plantă perenă erbacee. Florile galbene sunt grupate în inflorescențe de tip umbelă. Specie adaptată la diverse condiții de climă și sol. În condițiile Republicii Moldova plantele au înflorirea îndelungată (lunile mai-septembrie) fiind în legătură strânsă cu perioada semănatului, oferind albinelor nectar și polen.

Reynoutria sachalinensis (F. Schmidt) Nakai - Hrișca-de-Sahalin, troscotul gigant (familia Polygonaceae Juss.). Plantă perenă, erbacee, tolerantă la condițiile climatice, rezistentă la ger și secetă. Perioada de înflorire este îndelungată, 37-40 de zile (lunile iulie-octombrie), cea ce asigură cu hrană insectele polenizatoare toamna când sursele de hrană sunt mai puţine.

Cercetarea și identificarea plantelor noi cu potențial melifer prezintă o contribuție importantă în vederea îmbogățirii sortimentului de plante valoroase și utilizarea potențialului nectaro-polenifer al plantelor de cultură și a celor din flora spontană.

Cercetările au fost realizate cu suportul ANCD în cadrul proiectului „,Mobilizarea resurselor genetice vegetale, ameliorarea soiurilor de plante, valorificarea lor ca culturi furajere, melifere și energetice în circuitul bioeconomic", cifrul 20.80009.5107.02

\section{BIBLIOGRAFIE}

1. Bura M. Plantele melifere care înfloresc în luna martie. În: Ferma, 2008, nr. 3, 58 p.

2. Cîrnu, I. Flora meliferă. Ceres, București, 1980, 202 p.

3. Pîrvu C. Universul plantelor. Bucureşti, Enciclopedia, 2000, 909 p. 